\title{
The Potential of Mercury-Resistant Bacteria Isolated from Small-Scale Gold Mine Tailings for Accumulation of Mercury
}

\author{
Umi Chasanah ${ }^{1}$, Yulia Nuraini², Eko Handayanto ${ }^{2 *}$ \\ 1 Postgraduate Programme, Faculty of Agriculture, Brawijaya University, Jl. Veteran No 1 Malang 65145, \\ Indonesia \\ 2 Research Centre for Management of Degraded and Mining Lands, Faculty of Agriculture, Brawijaya University, \\ Jl. Veteran No 1 Malang 65145, Indonesia \\ * Corresponding author's e-mail: handayanto@ub.ac.id
}

\begin{abstract}
In certain small-gold mining activities in West Lombok, Indonesia, the tailings containing mercury are discharged to agricultural lands, reducing their productivity. One of the efforts to restore the land is by bioremediation of mercury, using mercury-resistant microbes. This study was aimed to isolate the mercury-resistant bacteria from smallscale gold mine tailings containing mercury, and to test their capability in accumulating mercury. Bacterial isolation and identification were conducted from nutrient broth supplemented with $5 \mathrm{ppm} \mathrm{HgCl}_{2}$. The isolated bacteria were tested for mercury accumulation in the nutrient broth containing 10,20 and $30 \mathrm{ppm} \mathrm{Hg}$ for 24 hours, and in small-scale gold mine tailing containing $41.37 \mathrm{ppm} \mathrm{Hg}$ for 2 weeks. The results showed that there were four pure isolates of mercury-resistant bacteria which were identified as Brevundimonas vesicularis, Nitrococcus mobilis, Fusobacterium aquatile and Fusobacterium necrogenes. The highest Hg accumulation from nutrient broth liquid media containing 10, 20 and $30 \mathrm{ppm} \mathrm{Hg}$ was observed for Brevundimonas vesicularis. The mercury accumulation efficiency of the four bacteria applied to small-scale gold mine tailing containing mercury was in the order of Fusobacterium aquatile $(76.1 \%)>$ Brevundimonas vesicularis $(75.6 \%)>$ Fusobacterium necrogenes $(74.4 \%)>$ Nitrococcus mobilis (74.2\%). On the basis of the $\mathrm{Hg}$ accumulation efficiency of more than $75 \%$, Fusobacterium aquatile and Brevundimonas vesicularis are prospective for bioremediation of mercury-contaminated soils.
\end{abstract}

Keywords: mercury-resistant bacteria, small-scale gold mine tailing

\section{INTRODUCTION}

Gold mining in Indonesia consists of largescale gold mining, medium-scale gold mining, and artisanal and small-scale gold mining (ASGM). In almost all ASGMs, the amalgamation process using mercury followed by cyanidation process is the method used to recover gold (Veiga et al., 2006). Amalgamation with mercury is a simple process and requires only a small investment. The mercury recovered from the amalgamation process is always reused in subsequent amalgamation processes. Tailings of the amalgamation and cyanidation processes in the form of sludge that still contain $\mathrm{Hg}, \mathrm{Au}$ and various other heavy metals, are generally discharged to the nearby agricultural land and water bodies. In every gram of gold produced, there are about 1-3 $\mathrm{g} \mathrm{Hg}$ released into the air, and partly released into the water, together with mud (Telmer, 2007). The results of a survey conducted by Krisnayanti et al. (2012a) at ASGM locations in Sekotong District of West Lombok showed that the amalgamation process tailing still contains $3002 \mathrm{mg} \mathrm{Hg} \mathrm{kg}{ }^{-1}$, on average. This high content of mercury in the waste of gold treatment process led to the increasing content of $\mathrm{Hg}$ in the soil contaminated with small-scale gold mining waste. The results of the analysis carried out by soil laboratory of Mataram University showed that the mercury levels in the soils of Sekotong District of West Lombok ranged from $25 \mathrm{mg} / \mathrm{kg}$ to $40 \mathrm{mg} \mathrm{kg}^{-1}$, while the mercury content in the seeds of maize and rice grown in the location of tailing disposal was around 0.20 
$\mathrm{mg} \mathrm{kg}^{-1}$ (Krisnayanti et al., 2012b). According to the Indonesian Ministry of Environment, no. 82 year 2001, the mercury threshold level in water and soil is $0.001 \mathrm{ppm}$. The discharge of tailings of amalgamation process which still contain very high concentrations of mercury in the agricultural lands, can disturb the growth and production of crops as well as harm human health through the consumption of the food produced from heavy metals-contaminated soil (Subowo et al., 2007). The plants that are poisoned by mercury will show the symptoms of chlorosis, brown plant root, root hood damaged, as well as decreased number and size of roots (Patra and Sharma, 2000). In addition to adverse affects to crops, mercury compound in the form of $\mathrm{Hg}$ (II) can be bound to the cysteine residues of human proteins so that proteins will lose their activity. In addition to $\mathrm{Hg}$ (II), the mercury compound that is most harmful to human health is an organic mercury compound; in particular, methyl mercury and phenyl mercury that are highly reactive and can attack the human nervous system through the bloodstream (Rasmussen et al., 2008). In relation to the above-mentioned matters, efforts are needed to detoxify mercury in the gold-mine tailings prior to the discharge to agricultural land in order not to hamper the plant growth and human health. One of efforts is the bioremediation of mercury using mercury-resistant microbes. Mercury can indeed kill some types of microbes, although there are some bacteria that are able to survive in an environment contaminated with mercury. The bacteria have a mechanism of resistance to the mercury contamination (Nascimento and Chartone-Souza, 2003). Some of the heterotrophic bacteria are resistant to mercury, like Pseudomonas, Psychrobacter spp. (Pepi et al., 2011), Nitrosomonas eutropha, Ralstonia eutropha, Sphingomonas sp. and Actinobacteria (Rasmussen et al., 2008). Bacterial resistance to mercury is the first step of the detoxification process. Detoxification of mercury, especially methyl mercury, is generally preceded by demethylation. Methyl mercury is demethylated into $\mathrm{Hg}^{2+}$ ion that is then later reduced to $\mathrm{Hg}^{\circ}$ that is volatile and less toxic (Barkay, 1992; Chang et al., 1998; Misra, 2000; Nascimento and Chartone-Souza, 2003). The mercury conversion process involves an enzyme complex comprising organomecurylyase and mercury reductase (Barkay, 1992; Chang et al., 1998; Misra, 2000; Nascimento and ChartoneSouza, 2003). The bacteria that are resistant to mercury are thought to have one or both of these enzymes allowing the mercury entering through the cytoplasmic membrane into the cell and accumulate. The bacteria that accumulate mercury can be used as biological agents which can be developed to clean up the environment contaminated with mercury or heavy metals. This study was aimed to isolate and identify indigenous bacteria that are able to accumulate mercury from smallscale gold mine tailings in West Lombok.

\section{MATERIALS AND METHODS}

\section{Location of bacterial isolation}

The study was conducted at microbiology laboratory of Brawijaya University from July to December 2016. The tailings of small-scale gold mining were obtained from the Sekotong District, West Lombok Regency located at 115046'$116^{\circ} 20^{\prime} \mathrm{E}$ and $8^{\circ} 25^{\prime}-8^{\circ} 55 \mathrm{~S}$ (Figure 1). The area is located at $400 \mathrm{~m}$ above the sea level with average annual rainfall of $1500 \mathrm{~mm}$. Composite samples of gold mine tailings from cyanidation processing facilities were collected from several points representing the tailing disposal areas. The laboratory analysis carried at Soil Science Department of Brawijaya University showed that the tailing samples had the following characteristics: $\mathrm{pH}$ 3.9; $0.08 \%$ organic $\mathrm{C}, 0.01 \%$ total $\mathrm{N}, 11.39 \mathrm{ppm}$ available $\mathrm{P}$, and $41.37 \mathrm{ppm}$ total $\mathrm{Hg}$. The value of total $\mathrm{Hg}$ exceeded the Indonesian Government threshold level of $\mathrm{Hg}$ in water and soil of $0.001 \mathrm{ppm}$.

\section{Bacterial isolation and identification}

Ten grams of tailings were mixed with $90 \mathrm{~mL}$ of sterile $0.85 \% \mathrm{NaCl}$ for 30 minutes. The mixture was then diluted into seven concentrations $\left(10^{-1}\right.$, $10^{-2}, 10^{-3}, 10^{-4}, 10^{-5}, 10^{-6}$, and $\left.10^{-7}\right)$. From each dilution, $0.5 \mathrm{~mL}$ suspension was drawn and poured into a petri dish containing nutrient broth medium that had been supplemented with $5 \mathrm{ppm} \mathrm{HgCl}_{2}$. The culture was then incubated for 48 hours. The bacterial colonies that grew in the medium were then purified to obtain pure isolates. Every isolate grown was then inoculated to the solid nutrient medium using the 16-stroke method and then incubated for 24 hours. Displacements of colony isolates were done three times. The colony parameters under observation were form, surface, edge, and colour of the colonies. Identification of bacteria was based on the system of Bergey's Manual of Determinative Bacteriology. In the 


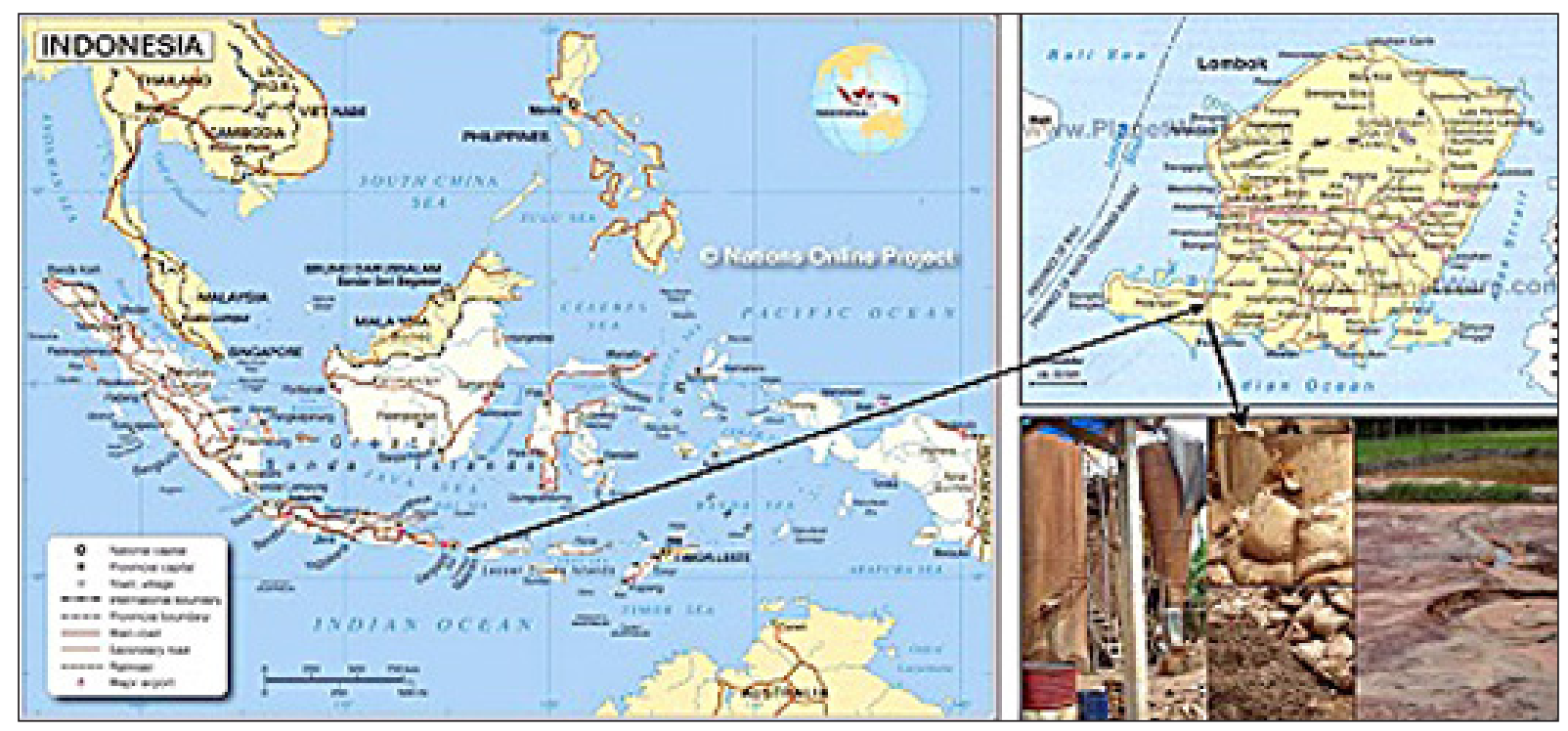

Figure 1. Sampling site of bacteria isolation at Sekotong District of West Lombok

early stages of identification of mercury+resistant bacteria, morphological tests were conducted using gram staining.

\section{Biochemical test of bacterial isolates}

The identified bacteria were then subjected to biochemical test that included carbohydrate fermentation, indole formation, $\mathrm{H}_{2} \mathrm{~S}$ production, motility, oxygen consumption, oxidase fermentation, citrate usage, catalase, and oxidase tests. Carbohydrate fermentation test was conducted using $15 \%$ glucose, $0.5 \%$ lactose and $0.5 \%$ mannitol media that each was dissolved in $100 \mathrm{~mL}$ of peptone water- $10 \% \mathrm{NaCl}$ and $1 \mathrm{~mL}$ of $0.1 \%$ bromthymol blue indicator. The bacterial isolates were inoculated into the fermentation medium and incubated for 24 hours at $37^{\circ} \mathrm{C}$. The Indole formation test was performed by inoculating bacteria in a liquid medium of Treptic Soy Broth $-10 \% \mathrm{NaCl}$ and then incubated for 24 hours at $37^{\circ} \mathrm{C}$; Kovacs reagent was added afterwards. Positive test result is marked with red colour formation (Cappuccino and Sherman, 2002). Test of production of $\mathrm{H}_{2} \mathrm{~S}$ and gas was carried out by inoculation of isolates to Triple Sugar Iron Agar $-10 \% \mathrm{NaCl}$ medium and further incubated for $24-$ 48 hours. The positive test of $\mathrm{H}_{2} \mathrm{~S}$ production is characterized by the formation of black colour on the medium. The positive test of gas formation is characterized by the formation of gas at the bottom of the medium (Cappuccino and Sherman, 2002). Motility of bacteria can be determined from the test of $\mathrm{H}_{2} \mathrm{~S}$ and gas production. Motility of bacteria is characterized by bacteria distribution in the former inoculation areas, which means that bacteria were mobile (motile). The test of oxygen demand was carried by inoculating the isolates to a mixture of agar, thioglycollate and $\mathrm{NaCl}$, which was then incubated for 48 hour at $37^{\circ} \mathrm{C}$ (Cappuccino and Sherman, 2002). The fermentation ability was observed by means of inoculation of bacteria in $10 \% \mathrm{NaCl}$ oxidase, $1 \%$ glucose at $37^{\circ} \mathrm{C}$ for 24 hours. The positive result is marked by a change in the medium to yellow. The test on the use of citric was conducted by inoculating the isolate in $5 \mathrm{~mL}$ of medium Simmons citrate- $10 \% \mathrm{NaCl}$ Agar and Bromthymol blue indicator then incubated at $37^{\circ} \mathrm{C}$ for 24 hours (Cappuccino and Sherman, 2002). The positive result is characterized by the growth of bacteria and the change of colour of the growing medium from green to blue. For catalase test, a drop of 3\% $\mathrm{H}_{2} \mathrm{O}_{2}$ was placed on top of a sterile glass slide and then the bacterial isolate was aseptically streaked. The positive results are marked by the emergence of gas or air bubbles around the scratches (Harley and Prescott, 2005). For oxidase test, the bacterial isolates were applied to the surface oxidase paper. The positive test result is obtained if the purple colour is formed on the oxidase paper after 5 seconds (Harley and Prescott, 2005).

\section{Preparation of growth curve for starter}

Aseptically, a single ose of 24-hours isolate (rejuvenated isolate on solid nutrient agar medium) was inoculated onto $10 \mathrm{~mL}$ nutrient broth 
(NB) liquid medium in a test tube, and then incubated for 24 hours on a rotary shaker (100 rpm). Afterwards, $5 \mathrm{~mL}$ was extracted from the 24-hour culture, and inoculated into $45 \mathrm{~mL}$ NB liquid medium with a concentration of $10 \mathrm{ppm} \mathrm{HgCl}_{2}$ in a beaker glass, and incubated for 24 hours on a rotary shaker (100 rpm). One milliliter of culture was then dissolved in $9 \mathrm{~mL}$ sterile distilled water and the value of its Optical Density was measured with a spectrophotometer (Boeco S-22, Germany) at a wavelength $(\lambda) 600 \mathrm{~nm}$. The Optical Density measurement was performed for 24 hours at 1-hour interval. The obtained Optical Density data were then used to prepare the growth curve with $\mathrm{x}$ axis as time ( $\mathrm{t}$ ) and $\mathrm{y}$-axis as Optical Density. Once the growth phase is known, the determination of starter can be determined, i.e. in the middle of the exponential phase.

\section{$\mathrm{Hg}$ accumulation capability test on nutrient broth liquid and tailing media}

$5 \mathrm{~mL}$ of bacterial starter $\left(10^{3} \mathrm{cfu} \mathrm{mL}^{-1}\right)$ culture was incorporated into a $250 \mathrm{~mL}$ beaker glass containing $50 \mathrm{~mL} \mathrm{NB}+\mathrm{HgCl}_{2}$ liquid medium. The treated concentrations of $\mathrm{HgCl}_{2}$ used were $10 \mathrm{ppm}$ ( $\left.5 \mathrm{ppm} \mathrm{NB}+0.5 \mathrm{ppm} \mathrm{HgCl}_{2}\right), 20 \mathrm{ppm}(5 \mathrm{ppm} \mathrm{NB}$ $+1.0 \mathrm{ppm} \mathrm{HgCl}_{2}$ ), and $30 \mathrm{ppm}$ (5 ppm NB + 1.5 ppm $\mathrm{HgCl}_{2}$ ). After incubation on a rotary shaker (100 rpm) for 24 hours (Badjoeri, 2008), the culture was then centrifuged $4000 \mathrm{rpm}$ for 20 minutes to separate the bacterial cell with the filtrate. The filtrate was placed into a test tube and two drops of $\mathrm{HNO}_{3}$ were added, and then placed in an autoclave for 30 minutes. $\mathrm{Hg}$ accumulation measurement was performed at 24 hours. For Hg accumulation capability test on small-scale gold mine tailing, each bacterial isolate as much as $0.1 \mathrm{~mL}\left(10^{3} \mathrm{cfu}\right.$ $\mathrm{mL}^{-1}$ ) was applied to small-scale gold mine tailing and incubated for 4 weeks. Hg accumulation measurements were made 1 week and 4 weeks after inoculation. All $\mathrm{Hg}$ measurements were performed using F732-S Cold Atomic absorption Mercury Vapor Analyzer (Shanghai Huaguang Instrument Company). The data obtained were subjected to analysis of variance at 5\% significance level.

\section{RESULTS AND DISCUSSION}

\section{Isolates of mercury resistant bacteria}

The result of isolation of mercury resistant bacteria showed a total population of $4.8 \times 10^{8}$. In the purification stage, there were seven selected isolates, but at the stage of gram staining there were only four pure isolates that grew on media containing $5 \mathrm{ppm} \mathrm{Hg}$. The medium used for the isolation of bacteria from gold mine tailings was nutrient agar that has been supplemented with $5 \mathrm{ppm} \mathrm{HgCl}_{2}$. According to Canstein et al. (2002) the isolation of bacterium isolate that can grow on synthetic media with a minimum of $5 \mathrm{ppm} \mathrm{HgCl}_{2}$ is a highly mercury-resistant bacterium isolate. In addition to the gram staining, the four isolates had different characteristics (colour and form colony shape) (Table 1). The results of biochemical tests of mercury resistant isolates are presented in Table 2 .

On the basis of the morphological characteristics and biochemical tests, as well as referring to Bergey's Manual of Determinative Bacteriology, isolate A was identified as Brevundimonas vesicularis. Another name of Brevundimonas vesicularis is Pseudomonas vesicularis (Segers et al., 1994). This bacterium is a gram-negative, rod-shaped, and aerobic bacterium. The diameter of bacterial colony was $2.05 \mathrm{~mm}$. The bacterium that can grow at temperatures of $26^{\circ} \mathrm{C}$ is motile. The colour of colony of this bacterium is generally orange. Brevundimonas vesicularis is capable of hydrolyzing esculin, and also able to assimilate D-glucose, maltose, L-ranose and acetate. Brevundimonas vesicularis is included in the protein Oma subclass bacteria that are effective in bio-sorption (Hu et al., 1996). Isolate B was identified as Nitrococcus mobilis. This bacterium is a gram-negative, cocci shaped, $2.03 \mathrm{~mm}$ diameter colony, colony colour was beige, and grew at a temperature of $25-30^{\circ} \mathrm{C}$ at $\mathrm{pH}$ of $7.8-8$. This group of bacteria is chemoautotrophic because it uses inorganic nitrogen compounds in its life cycle (Madigan et al., 2009). Nitrococcus mobilis is a nitrifier that can oxidize nitrite to nitrate $\left(\mathrm{HNO}_{2}+\right.$ $\mathrm{H}_{2} \mathrm{O}$ à $\mathrm{HNO}_{3}$ ) (Bartosch et al., 1999). Isolates $\mathrm{C}$ and D were identified as Fusobacterium aquatile and Fusobacterium necrogenes, respectively. Fusobacterium is a genus of anaerobic, gram-negative bacterium with rod shape. Fusobacterium aquatile can ferment several types of sugar and produces catalase enzymes (Komala et al., 2012). Fusobacterium aquatile and Fusobacterium necrogenes are able to produce energy from oxidation of inorganic chemicals. The habitat of the bacteria involves soil, waste, aquatic environments, and natural environments that contains sulfur, iron or manganese, such as acid mine water and sulfur hot springs (Madigan and Martinko, 2006). 
Table 1. Morphological characteristics of four isolates of mercury resistant bacteria

\begin{tabular}{|c|c|c|c|c|}
\hline \multirow{2}{*}{ Parameter } & \multicolumn{4}{|c|}{ Isolates } \\
\hline & S-1 (A) & S-2 (B) & S-3(C) & S-4 (D) \\
\hline Colony & Orange & Cream & Cream & Yellow \\
\hline Colour & - & & & \\
\hline Colony shape & round & round & round & round \\
\hline Colony diameter $(\mathrm{mm})$ & 2.05 & 2. 03 & 0.74 & 0.67 \\
\hline Colony edge & not flat & not flat & flat & flat \\
\hline Elevation & convex & convex & convex & convex \\
\hline Consistency & dry & dry & dry & wet \\
\hline Gram reaction & negative & negative & negative & negative \\
\hline Cell shape & rod & cocci & rod & rod \\
\hline
\end{tabular}

Table 2. Biochemical test on four mercury-resistant isolates

\begin{tabular}{|c|c|c|c|c|c|}
\hline \multirow{2}{*}{ No } & \multirow{2}{*}{ Biochemical test } & \multicolumn{4}{|c|}{ Isolates } \\
\hline & & S-1 (A) & S-2 (B) & S- 3(C) & S-4 (D) \\
\hline 1 & Spore & - & - & - & - \\
\hline 2 & Oxidase & + & - & - & - \\
\hline 3 & Motility & + & - & + & + \\
\hline 4 & Nitrate & + & + & + & + \\
\hline 5 & Lysine & - & - & - & - \\
\hline 6 & Ornithine & - & - & - & - \\
\hline 7 & $\mathrm{H}_{2} \mathrm{~S}$ & - & - & - & - \\
\hline 8 & Glucose & - & + & - & - \\
\hline 9 & Mannitol & + & - & - & + \\
\hline 10 & Xylose & - & - & - & - \\
\hline 11 & Indole & - & - & + & - \\
\hline 12 & Urease & - & - & + & - \\
\hline 13 & Citric & - & - & - & - \\
\hline 14 & Gelatin & + & - & - & - \\
\hline 15 & Malonate & - & - & - & - \\
\hline 16 & Inositol & - & - & - & - \\
\hline 17 & Rhamnosa & - & - & - & - \\
\hline 18 & Sorbitol & - & - & - & 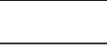 \\
\hline 19 & Sucrose & - & + & + & + \\
\hline 20 & Lactose & - & - & - & - \\
\hline 21 & Arabinose & - & - & + & - \\
\hline 22 & Adonitol & - & - & - & - \\
\hline 23 & Raffinosa & - & - & - & - \\
\hline 24 & Salicin & - & - & + & - \\
\hline 25 & Arginine & - & - & - & - \\
\hline 26 & Catalase & + & + & - & - \\
\hline 27 & Coagulase & - & - & - & - \\
\hline 28 & Beta hemolysis & - & - & - & - \\
\hline 29 & Starch hydrolysis & + & + & + & + \\
\hline 30 & Casein hydrolysis & - & - & - & - \\
\hline
\end{tabular}




\section{Growth of bacteria}

The growth of four isolates of mercury-resistant bacteria (Brevundimonas vesicularis, $\mathrm{Ni}$ trococcus mobilis, Fusobacterium necrogenes and Fusobacterium aquatile) for 58 hours of incubation showed a uniform pattern (Figure 2). The stationary phase that was the best time for the production of bacterial cell numbers of Brevundimonas vesicularis and Nitrococcus mobilis, was at 36 hours, while that of Fusobacterium necrogenes and Fusobacterium aquatile was at 42 hours (Figure 2). The stationary phase difference presented in Figure 2 was probably due to the resistance mechanism of each of the different bacterium. The bacterial growth is the addition of cells and the ability of bacteria to breed that can be illustrated with a growth curve (Cooper, 1991). The growth curve depicts the pattern of bacterial growth that can be divided into four phases: lag, exponential, stationary, and death (Harley and Prescott, 2005). The growth curve corresponds to the bacterial growth curve, which is generally in the form of a sigmoid curve (Harley and Prescott,
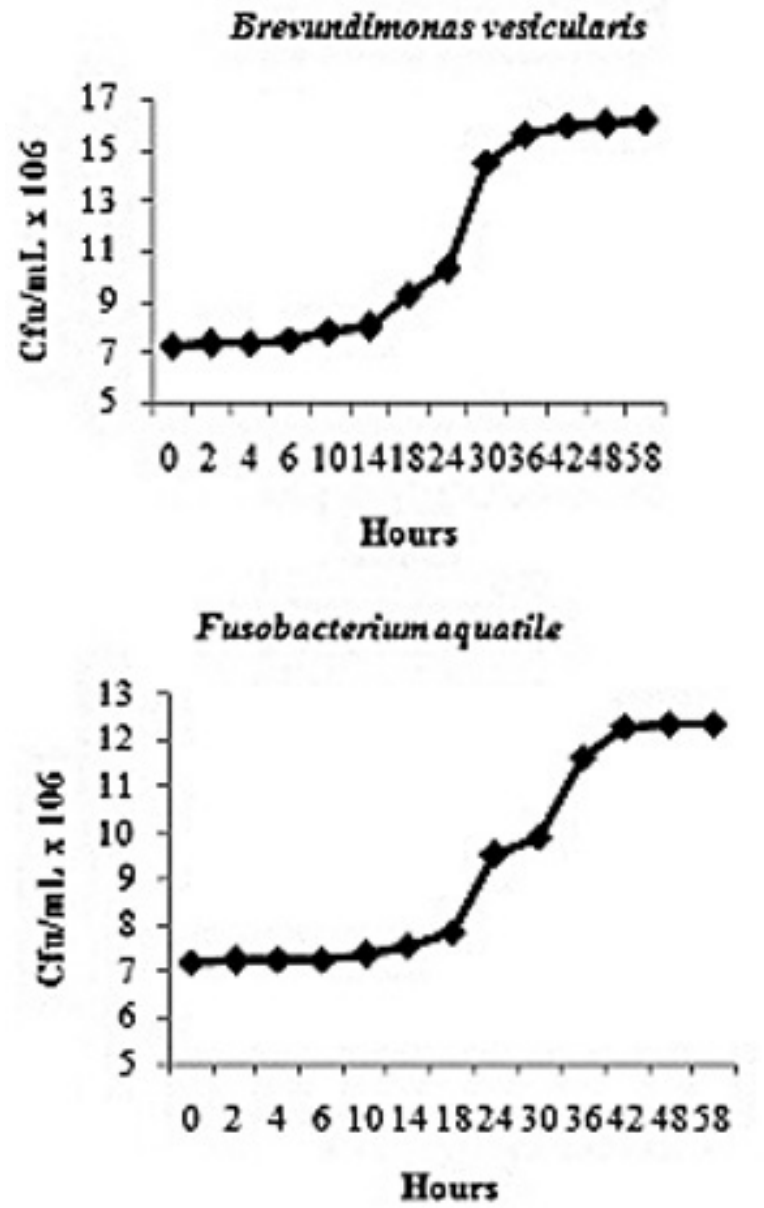

2005). The starter lifetime can be determined from the exponential mid-phase. According to Hogg (2005), at the exponential phase, microorganism cells are in stable state, new cells are formed at a constant rate and microorganism cells divide optimally during the doubling time so that it is usually reached in the middle of an exponential phase.

The presence of the four identified bacteria (Brevundimonas vesicularis, Nitrococcus mobilis, Fusobacterium aquatile and Fusobacterium necrogenes) in the environment containing mercury is because the bacteria have the genes that are resistant to mercury (Mer Operon). Highly mercury-resistant bacteria have mer operon that encodes flavoenzime, a mercury reductase that can reduce $\mathrm{Hg}^{2+}$ ion to the less toxic $\mathrm{Hg}^{0}$ (Vetriani et al., 2004). The mercury resistant gene is generally composed of a metal regulator gene (MerR), a mercury transport gene (MerT, MerP, MerC), a reductase mercury gene (MerA) and an organo mercurylyase (MerB) (Brown et al., 2002; Nofiani and Gusrizal, 2004). The results of a study reported by Lima de Silva et al. (2012)
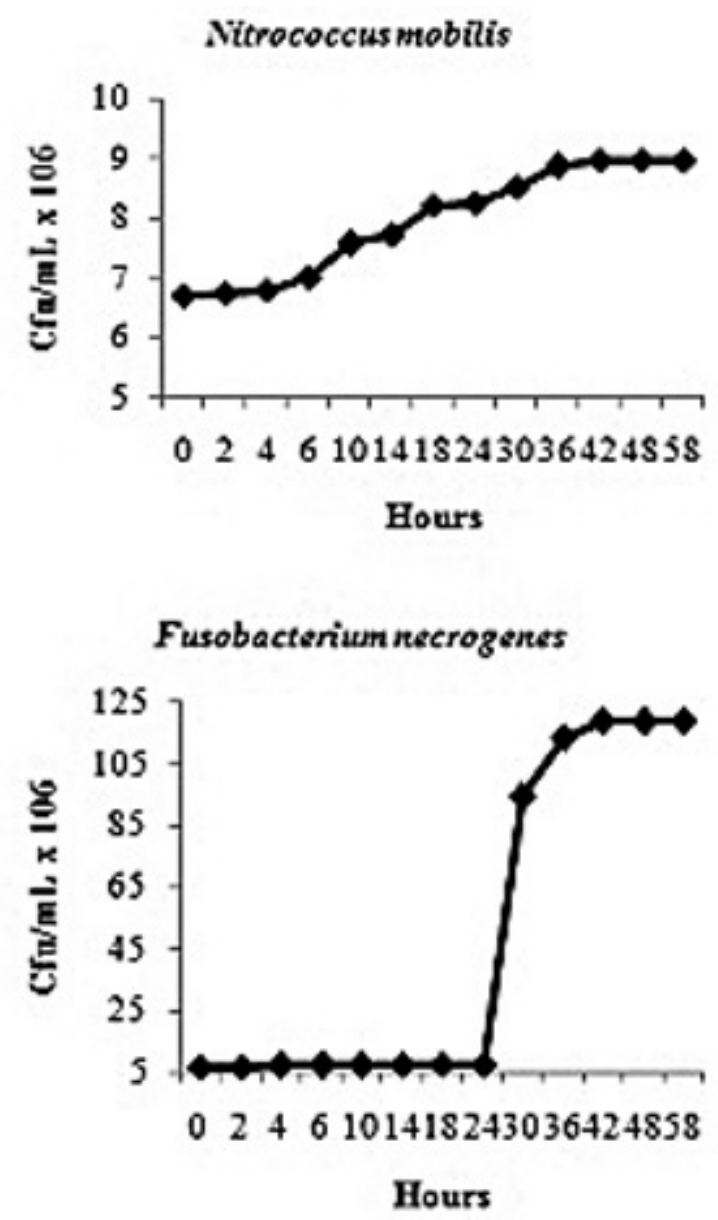

Figure 2. Growth of four isolates of mercury-resistant bacteria 
showed that Brevundimonas vesicularis was one of strains found in the media containing mercury $\left(\mathrm{HgCl}_{2}\right)$. Irawati et al. (2012) reported that Brevundimonas $s p$. accumulated $\mathrm{Hg}^{2+}$ up to 1.09 and $2.7 \mathrm{mg} \mathrm{g}^{-1}$ dry weight of cells and removed 64.38 and $57.10 \% \mathrm{Hg}^{2+}$ from the medium containing 50 and $100 \mathrm{ppm} \mathrm{HgCl}_{2}$, respectively.

\section{Mercury accumulation from nutrient broth liquid media}

After incubation for 24 hours, the highest $\mathrm{Hg}$ accumulation was observed for bacteria A (Brevundimonas vesicularis), i.e. $1.68,2.08$, and 2.17 ppm $\mathrm{Hg}$ at 10,20 , and $30 \mathrm{ppm} \mathrm{Hg}$ treatments, respectively (Figure 1). Meanwhile, bacteria D (Fusobacterium necrogenes) performed the lowest $\mathrm{Hg}$ accumulation at all treatments (Figure 3). In general, bacteria A (Brevundimonas vesicularis) accumulated $\mathrm{Hg}$ higher than other bacteria at all treatments of $\mathrm{Hg}$ concentrations, except for $\mathrm{Ni}$ trococcus mobilis and treatment $\mathrm{Hg}$ concentration treatment of $30 \mathrm{ppm} \mathrm{Hg}$. However, the difference of $\mathrm{Hg}$ accumulation by Brevundimonas vesicularis and Nitrococcus mobilis at the treatment of $30 \mathrm{ppm} \mathrm{Hg}$ was not significant. The decrease of $\mathrm{Hg}$ concentration in nutrient broth media is because the organic and inorganic materials in the medium are able to bind or react with different types of metals. Some organic compounds, such as polysaccharides, humic or protein can react with metal ions by redox or binding reactions that form metal-organic complexes, but these bindings are influenced by environmental factors (Buffle et al.,
1994). The decrease of mercury concentration in the cultures containing mercury-resistant bacteria occurs also because the bacteria have cytosolic flavoenzyme mercury ion reductase that catalyzes the reduction of $\mathrm{Hg}^{2+}$ to $\mathrm{Hg}^{0}$ with NADPH as the electron donor (Fox and Walsh, 1982; Zeroual et al., 2003). The formed $\mathrm{Hg}^{0}$ is eliminated from the cell by passive diffusion under normal physiological conditions, due to the high vapour pressure of mercury metal, resulting in the evaporation of mercury from the medium (Chang et al., 1999). This process is a mercury detoxification in which the mercury metal formed is volatile, so it can penetrate out of the medium (Barkay et al., 2003).

\section{Mercury accumulation from small-scale gold mine tailing}

After 1 week incubation, the highest accumulation of $\mathrm{Hg}$ (31.34 ppm) was found in the bacteria A treatment (Brevundimonas vesicularis), whereas the lowest $\mathrm{Hg}$ accumulation (29.62 ppm) was observed in the bacteria D treatment (Fusobacterium necrogenes) (Figure 4). This was in agreement with $\mathrm{Hg}$ accumulation in nutrient broth liquid media where Brevundimonas vesicularis was the best $\mathrm{Hg}$ accumulator (Figure 3). After 4 weeks, $\mathrm{Hg}$ accumulation by Brevundimonas vesicularis was still high, although the value was slightly lower than that at 1 week. While the $\mathrm{Hg}$ accumulation by Fusobacterium aquatile and Nitrococcus mobilis at 4 weeks remained constant, the $\mathrm{Hg}$ accumulation by Fusobacterium aquatile and Fusobacterium necrogenes increased (Figure 3). This was

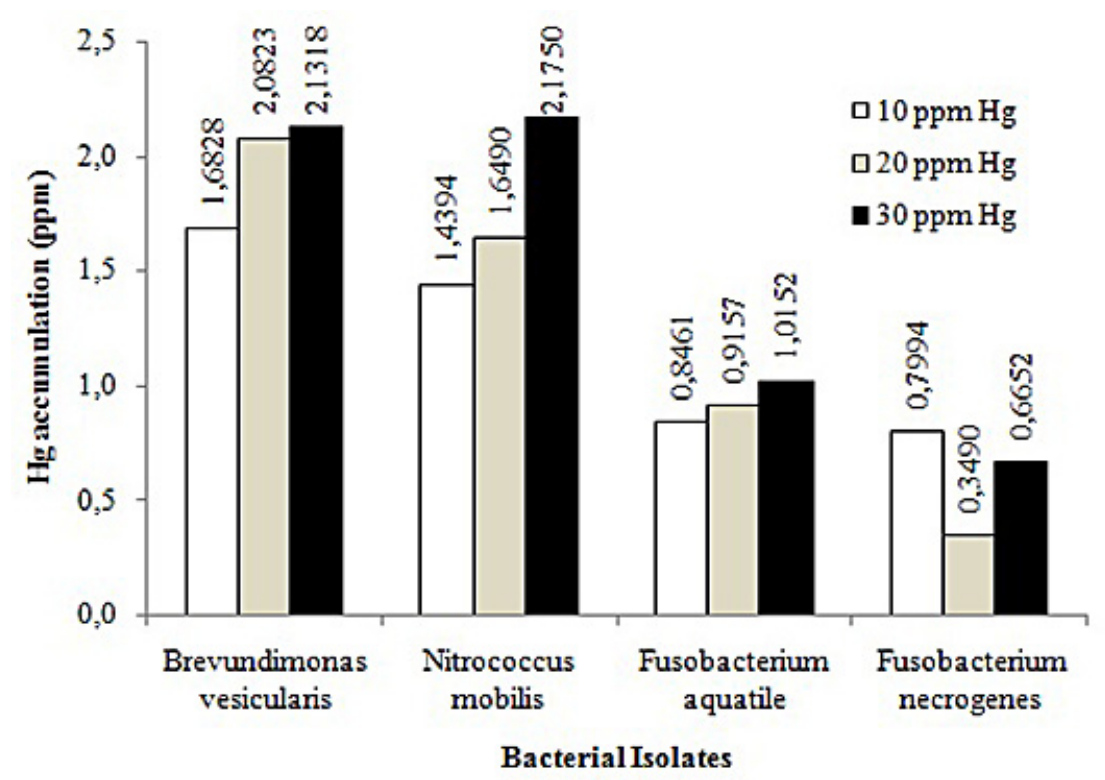

Figure 3. Accumulation of mercury by isolates of mercury resistant bacteria from nutrient broth liquid medium 


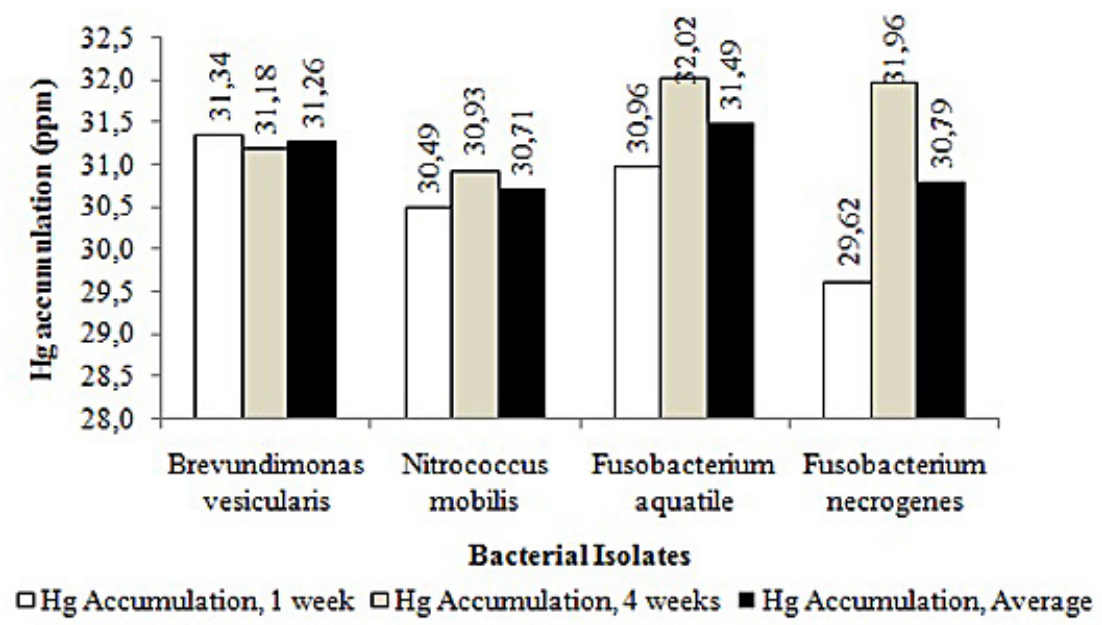

Figure 4. Accumulation of mercury by four isolates of mercury resistant bacteria in small-scale gold mine tailing

related to the growth of the bacteria (Figure 2). The stationary phase of Brevundimonas vesicularis and Nitrococcus mobilis, was at 36 hours, while that of Fusobacterium necrogenes and Fusobacterium aquatile was at 42 hours. The stationary phase is the best time for the production of bacterial cell numbers.

In comparison with the initial $\mathrm{Hg}$ concentration in tailings (41.37 ppm), at 1 week, the highest Hg accumulation efficiency (75.8\%) was observed for Brevundimonas vesicularis followed by Fusobacterium aquatile (74.8\%), Nitrococcus mobilis (73.7\%, and Fusobacterium necrogenes $(71.6 \%)$. At 4 weeks, however, the highest $\mathrm{Hg}$ accumulation efficiency $(76.6 \%)$ was observed for Fusobacterium aquatile followed by Brevundimonas vesicularis (75.6\%), Fusobacterium necrogenes (74.4\%), and Nitrococcus mobilis $(74.2 \%)$. The accumulation efficiency of $\mathrm{Hg}$ in four bacterial isolates tended to increase at 4 weeks incubation, except for Brevundimonas vesicularis. The signs of bacterial life indicated that the accumulation process was still ongoing, so the efficiency of accumulation at four weeks was higher than that of one week of incubation, although the difference was not significant. On average, the $\mathrm{Hg}$ accumulation capability of the mercury-resistant bacteria isolated from small-scale gold mine tailings was in order of Fusobacterium aquatile $(76,1 \%)>$ Brevundimonas vesicularis $(75,6 \%)>$ Fusobacterium necrogenes $(74,4 \%)>$ Nitrococcus mobilis $(74,2 \%)$. The process of bacterial resistance to mercury ions $\left(\mathrm{Hg}^{2+}\right)$ via the reaction of the ligand binding and enzymatic reactions that can reduce $\mathrm{Hg}^{2+}$ into volatile $\mathrm{Hg}^{0}$, so $\mathrm{Hg}^{2+}$ will not poison the bacterial cells (Nascimento and Chartone-Souza, 2003). The bacterial resistance to mercury can be through the mechanisms of biosorption and accumulation. The biosorption mechanism is a passive process, so that the metal is not toxic to the bacterial cell. The accumulation mechanism is an active process in which heavy metals are toxic to the bacterial cell (Chojnacka, 2010). According to Iyer et al. (2005), the biosorbtion mechanism is associated with the presence of exopolysaccharide in the bacterial cell wall that serves as chelating heavy metals on the cell surface. Complex molecules on the bacterial cell wall consist of peptidoglycan that is composed of simple molecules such as phosphoryl, carboxyl, and amino acids that have a negative charge. The negative charge will interact with the ions or molecules with a positive charge on the outside environment that shaped the bonding ligand. Metal ions are positively charged, so that they bind to the cell surface electrostatically (Langley and Baveridge, 1999).

\section{CONCLUSION}

Four isolates of mercury-resistant bacteria i.e. Brevundimonas vesicularis, Nitrococcus mobilis, Fusobacterium aquatile, and Fusobacterium necrogenes could be isolated from smallscale gold mine tailings from Sekotong District of West Lombok. The highest $\mathrm{Hg}$ accumulation from nutrient broth liquid media was observed for Brevundimonas vesicularis at all $\mathrm{Hg}$ treatments, while Fusobacterium necrogenes performed the lowest $\mathrm{Hg}$ accumulation. The highest mercury accumulation from small-scale gold mine tailing containing mercury (average of 1 week and 4 weeks incubation) was by Fusobacterium aqua- 
tile followed by Brevundimonas vesicularis, $\mathrm{Fu}$ sobacterium necrogenes, and Nitrococcus mobilis. On the basis of the $\mathrm{Hg}$ accumulation efficiency of more than $75 \%$, Fusobacterium aquatile and Brevundimonas vesicularis are potential for bioremediation of mercury-contaminated soils.

\section{Acknowledgements}

The authors wish to thank Dean of the Faculty of Agriculture, Brawijaya University for financial support through BOPTN research grant 2016. Very valuable technical assistance and support from staff of Biology Laboratory of the Faculty of Basic Sciences, Brawijaya University are highly appreciated.

\section{REFERENCES}

1. Badjoeri M. 2008. Capability test of Bacillus megaterium in absorbing mercury heavy metal. Limnology Research Centre, LIPI: Bogor (in Indonesian).

2. Barkay T. 1992. Mercury Cycle. Encyclopedia of Microbiology $3^{\text {rd }}$ Ed. Academic Press. Inc. New York. 3: 65-74.

3. Barkay T., Miller S.M., Summers A.O. 2003. Bacterial mercury resistancefrom atoms to ecosystems. FEMSMicrobiol. Rev. 27: 355-384.

4. Bartosch S., Wolgast I., Spiek E., Bock E. 1999. Identification of nitrite-oxidizing bacteria with monoclonal antibodies recognizing the nitrite oxydoreductase. Applied and Environmental Microbiology, 65 (6), 4126-4133.

5. Brown N.L., Shih Y.C., Leang C., Glendinning K.J., Hobman J.L., Wilson J. 2002. Mercury transport and resistance. Biochemical Society Transactions, 30(4),715-718.

6. Buffle, J., Stumm W. 1994. General Chemistry of Aquatic Systems. In: Chemical and Biological Regulation of Aquatic Systems, J. Buffle and R.R. De Vitre (Eds). Lewis Publishers, Tokyo. P-42.

7. Canstein H.V., Kelly S., Li Y., Wagner-Dobler I. 2002. Species diversity improves the efficiency of mercury-reducing biofilm under changing environmental conditions. Applied and Environmental Microbiology, 68(6), 2829-2837.

8. Cappuccino J.G., Sherman N. 2002. Microbiology: a laboratory manual $\left(8^{\text {th }}\right.$ edition,) Pearson. ISBN13: 978-0805325782.

9. Chang J.S., Chao Y.P., Law W.S. 998. Repeated fed-batch operations for microbial detoxification of mercury using wild type and recombinant mercury-resistant bacteria. Journal of Biotechnology, 64 (2-3), 219-230.
10. Chang J.S., Hwang Y.P., Fong Y.M., and Lin P.J. 1999. Detoxification of mercury by immobilized mercuric reductase. Journal of Chemical Technology and Biotechnology,74(10), 965-973.

11. Chojnacka K. 2010. Biosorption and bioaccumulation, the prospects for practical applications. Environment International, 36, 299-307.

12. Cooper S, 1991. Bacterial Growth and Division: Biochemistry and Regulation of Prokaryotic and Eukaryotic Division Cycles, Academic Press: San Diego, p. 501.

13. Fox B., Walsh C.T. 1982. Mercuric reductase: purification and characterization of a transposonencoded flavoprotein containing an oxidationreduction-active disulfide. Journal of Biological Chemistry, 257, 2498-2503.

14. Harley J.P., Prescott L.M. 2005. Laboratory Exercises in Microbiology, 6th Edition. The McGraw Hill Higher Education, Boston, MA.

15. Hu M.Z.C., Norman J.M., Faison, N.B., Reeves, M. 1996. Biosorption of uranium by Pseudomonas aeruginosa strain CSU: characterization and 287288 comparison studies. Biotechnology and Bioengineering, 51, 237-247.

16. Irawati W., Patricia, Soraya Y., Baskoro A.H. 2012. A study on mercury-resistant bacteria isolated from a gold mine in Pongkor Village, Bogor, Indonesia. Hayati Journal of Bioscience, 19(4), 197-200.

17. Jyer A., Mody K., Jha B. 2005. Biosorption of heavy metals by a marine bacterium. Marine Pollution Bulletin, 50, 340-343.

18. Komala P.S., Helard, D., Delimas, D. 2012. Identification of dominant anaerobic microbes in rubber mill waste treatment with multi soil layering system. Journal of Environmental Engineering, Andalas University, 9 (1), 74-88 (in Indonesian).

19. Krisnayanti B.D., Anderson C.W.N., Utomo W.H., Feng X., Handayanto E., Muddarisna N., Ikram H., and Khususiah. 2012a. Assessment of environmental mercury discharge at a four-year-old artisanal gold mining area on Lombok Island, Indonesia. Journal of Environmental Monitoring, 14, 2598-2607.

20. Krisnayanti B.D., Arifin Z., Bustan, Sudirman, Yani A. 2012b. Mercury Concentration on Tailing and Water from One Year of ASGM at Lantung, Sumbawa, Indonesia. In: Environmental, Socioeconomic, and Health Impacts of Artisanal and Small-Scale Minings. E. Handayanto, B.D. Krisnayanti and Suhartini (eds). UB Press, Malang, Indonesia, pp. 61-66.

21. Langley S., Beveridge T.J. 1999. Effect of O-side chine lipopolysaccharide chemistry on metal binding. Applied and Environmental Microbiology, 65, 489-498.

22. Lima de Silva A.A., Ribeiro de Carvalho M.A.L., de Souza S,A., Teixeira Dias P.M., da Silva Filho 
R.G., de Meirelles Saramago C.S., de Melo Bento C.A., Hofer E. 2012. Heavy metal tolerance (Cr, $\mathrm{Ag}$, and $\mathrm{Hg}$ ) in bacteria isolated from sewage. Brazilian Journal of Microbiology, 43(4), 1620-1631.

23. Madigan M.T., Martinco J.M., Dunlop P.V., Clark D.P. 2009. Brock Biology of Microorganisms. Twelfth Edition, 403-404.

24. Madigan T., Martinko J.M., 2006. Brock Biology of Microorganisms, 11th edpp.992,Prentice Hall, Upper Saddle River, NJ, USA.

25. Misra, T.K. 2000. Heavy Metals Bacterial Resistance. Encyclopedia of Microbiology 2nd Ed. 2: 618-627.

26. Nascimento A.M.A., Chartone-Souza E. 2003. Operon mer: Bacterial resistance to mercury and potential for bioremediation of contaminated environments. Genetics and Molecular Research, 2(1), 92-101.

27. Nofiani R., Gusrizal. 2004. Narrow spectra mercury resistance bacteria from former illegal gold mining Mandor West Kalimantan. Jurnal Natur Indonesia, 6(2): 67-74. (in Indonesian).

28. Patra M., Sharma A. 2000. Mercury toxicity in plants. Botanical Review, 66, 379-422.

29. Pepi M., Carlo G., Emanuele B., Silvia F., Arianna L., Marcella R., Valentina N., Margherita V., Simone G., Giuseppe T., Paola R., Silvano E. 2011. Mercury-resistant bacterial strains Pseudomonas and Psychrobacter spp. isolated from sediments of Orbetello Lagoon (Italy) and their possible use in bioremediation processes. Int. Biodeterior. Biodegradation, 65, 85-91.

30. Rasmussen L.D., Zawasdsky C., Binnerup S.J., Oregaard G., Soresnsen S.J., Kroer N. 2008. Cultivation of hard-to-culture subsurface mercury-re- sistant bacteria and discovery of new merA gene sequence. Applied and Environmental Microbiology, 74(12), 3795-3803.

31. Segers P., Vancanneyt L.M., Pot B., Torck U., Hoste B., Dewettinck D., Falsen E., Kersters K., De Vos P. 1994. Classification of Pseudomonas diminuta Leifson and Hugh 1954 and Pseudomonas vesicularis Busing, Doll, and Freytag 1953 in Brevundimonas gen. nov.as Brevundimonas diminuta comb. nov. and Brevundimonas vesicularis comb. nov., respectively. International Journal of Systematic Bacteriology, 44 (3), 499-510.

32. Subowo M., Widodo S., Nugraha A. 2007. Status and distribution of $\mathrm{Pb}, \mathrm{Cd}$, and pesticides on intensified rice fields on the edge of the highway. Proceedings of Chemistry and Soil Biotechnology, Puslittanak, Bogor (in Indonesian).

33. Telmer K. 2007. Mercury and small scale gold mining-magnitude and challenges worldwide. GEF/UNDP/UNIDO Global Mercury Project.

34. Veiga M.M., Maxson P.A., Hylander L.D. 2006. Origin and consumption of mercury in small-scale gold mining. Journal of Cleaner Production, 14, 436-447.

35. Vetriani C., Speck M.D., Ellor S.V., Lutz R.A., Starovoytov V. 2004. Thermovibrio ammonificans sp. nov., a thermophilic, chemolithotrophic, nitrateammonifying bacterium from deep-sea hydrothermal vents. International Journal of Systematic and Evolutionary Microbiology, 54, 175-181.

36. Zeroual Y., Moutaouakkil A., Dzairi F.Z., Talbi M., Chung P.U., Lee K., Blaghen M. 2003. Purification and characterization of cytosolic mercuric reductase from Klebsiella pneumonia. Annals of Microbiology, 53, 149-160. 